\title{
THE EFFECTS OF THE EU FOREIGN POLICY INSTRUMENTS UPON THIRD COUNTRIES
}

$* * *$

\section{AB DIŞ POLITIKA ARAÇLARININ ÜÇÜNCÜ ÜLKELER ÜZERINDEKİ ETKISI}

\author{
Doç. Dr. Gökhan AKŞEMSETTINOĞLU \\ Çankaya Üniversitesi \\ İktisadi ve İdari Bilimler Fakültesi \\ Siyaset Bilimi ve Uluslararası İlişkiler Bölümü \\ gokhana@cankaya.edu.tr \\ ORCID: 0000-0002-6990-6834
}

\begin{abstract}
The Lisbon Treaty took concrete steps to strengthen the foreign policy area of the European Union (EU). For instance, the European Commission constituted Foreign Policy Instruments to affect third countries with different financial and operational actions. In the EU, decisions on foreign policy require unanimity of member states. Unanimity indicates the determination of the member states to meet on a common ground on foreign policy and reflects the level of political integration of the EU. Accordingly, examining the effects of the EU Foreign Policy Instruments upon third countries can inform us about the level of political integration of the EU. This article, by using the case study methodology, intends to exemplify the EU Foreign Policy Instruments and to find out their effects upon third countries and some non-state actors. The research covers the developments of the last decade and concludes that the EU Foreign Policy Instruments are still not effective enough to change the policies and behaviours of the third countries. This conclusion indicates that the EU member states do not have a common accord on foreign policy and political integration in the EU seems unlikely in the near future.
\end{abstract}

Keywords: European Union, EU Foreign Policy Instruments, Political Integration.

\section{$\ddot{O} z$}

Lizbon Antlaşması Avrupa Birliği (AB) ’nin dış politika alanını güçlendirmek için somut adımlar atmıştır. Örneğin, Avrupa Komisyonu, üçüncü ülkeleri farklı mali ve işlevsel eylemlerle etkilemek için Dış Politika Araçları oluşturmuştur. AB'de dış politika kararları üye ülkelerin oybirliğini gerektirir. Oybirliği, üye devletlerin diş politika konusunda ortak bir noktada buluşma kararlılı̆̆ına işaret eder ve AB'nin siyasi bütünleşme düzeyini yansıtır. Dolayısıla, AB Dış Politika Araçlarının üçüncü ülkeler üzerindeki etkisini incelemek bize AB'nin siyasi bütünleşme düzeyi hakkında bilgi verebilir. Bu makale, vaka çalışması metodunu kullanarak, AB Dış Politika Araçlarını örnekleyerek açıklamayı ve bu araçların üçüncü ülkeler ve bazı devlet dışı aktörler üzerindeki etkilerini bulmayı amaçlamaktadır. Araştırma, son on yıl içindeki gelişmeleri kapsamakta ve AB Dış Politika Araçlarının üçüncü ülkelerin politikalarını ve davranışlarını değiştirme konusunda hala yeterli bir etkiye sahip olmadığına hükmetmektedir. Bu sonuç, AB üyesi devletlerin dış politika konusunda ortak bir mutabakata sahip olmadıklarına ve AB'de siyasi bütünleşmenin de yakın bir gelecekte mümkün görünmediğine işaret etmektedir.

Anahtar Sözcükler: Avrupa Birliği, AB Dış Politika Araçlarl, Siyasal Bütünleşme. 
Akademik Araştırmalar ve Çalışmalar Dergisi Y1l: 2020, 12(22): 164-179

Makale Türü: Araştırma Makalesi
Journal of Academic Researches and Studies Year: 2020, 12(22): 164-179

Paper Type: Research Paper 


\section{INTRODUCTION}

When Robert Schuman, the French Foreign Minister, proposed to integrate the French and German coal and steel industries under a higher authority, on 9 May 1950, he had intended to constitute a united Europe by way of pursuing Franco-German rapprochement and a market integration. In this proposition, although the means for unification was economic, the original goal was totally political. The then British Prime Minister Harold Macmillan said: "the most important motive behind the movement for European integration is the need to attach Germany permanently to Western Europe, but in such a manner that she cannot dominate it" (Henig, 2002:6). In the course of time, the member states of the European Community/Union have managed to take effective steps on economic and monetary union and even achieved to print a single money. However, they have not gained worthwhile momentum on realizing the original goal that is political integration. Therefore, the member states of the European Union (EU) have put the political integration on their agenda for the last decade, in particular. In this context, issues regarding foreign policy, as an indication of political integration, have come into prominence for the member states' governments of the EU.

In the EU, foreign policy is an intergovernmental issue and decisions on foreign policy require unanimity of member states. In the EU, foreign policy decisions of the member states reflect their national interests on the one side and to what extent they find a middle ground with the other member states, on the other side. Therefore, unanimity-required issues such as foreign policy can indicate both the level of agreement among the member states and the level of agreement on the political integration. We can test the effects of the EU foreign policy on third countries. Effective foreign policy decisions can influence the policies of third countries and even change their behaviours. Understanding such effects can indicate the level of agreement among the EU member states on foreign policy and how far they are from the original objective of the European integration project that is political integration. These effects also put forward the power status of the EU among other global actors on the international stage.

The article is composed of four main sections. The first section is preliminary for the article. This section is consisted of theory and history. The theory subsection explains the main approaches of integration, emphasizing both the foreign policy and the political integration. The history subsection deals with a short historical background of the European integration process from the foreign policy point of view. The second section, the external action, is about the High Representative of the Union for Foreign Affairs and Security Policy (HR/VP) ${ }^{1}$ and the European External Action Service (EEAS). The third section is the main section of the article. It is related with the five main and the three regulatory EU Foreign Policy Instruments and their effects upon third countries. The fourth section is a commentary on the article. It makes a remark on the level of the effectiveness of the EU Foreign Policy Instruments upon third countries.

\section{THEORETICAL and HISTORICAL BACKGROUND}

\subsection{Theory}

Short theoretical framework can give us an insight about understanding the substructure of the EU foreign policy and comprehending the driving force behind the political integration. In fact, the Schuman proposition was based on the idea of technical/functional cooperation in which the rules, the experts, and the principles of a "technical self-determination" are the component parts (Mitrany, 1943:35) Therefore, inspired by Mitrany's functionalism, Robert Schuman and Jean Monnet ${ }^{2}$ created "functional method" and focused on technical, sector-specific integration in order to establish a territorial based organization (Cini and Borragan, 2013:16). As a matter of fact, neo-functionalists believed that the

\footnotetext{
${ }^{1}$ The High Representative of the Union for Foreign Affairs and Security Policy is the Vice-President of the European Commission.

${ }^{2}$ Jean Monnet as the Commissioner-General of the French National Planning Board considered that economic cooperation with Germany was essential. Therefore, he became the main inspiration behind the Schuman Declaration. Thus, Jean Monnet and Robert Schuman are known as the founding fathers of the European integration process.
} 
economic integration would lead to the political integration ${ }^{3}$. Therefore, neo-functionalism became the main theory explaining the European integration process, in its earlier years, in particular.

In the second half of the 1980s, "new institutionalism" has made a connection between the decisions of political actors and institutions (March and Olsen, 1984:734-749). Therefore, the new institutionalism has constituted a proper framework for the member states to define the foreign policy interests and the decisions of the political actors (Keukelerie and Delreux, 2014:324). All three versions of the new institutionalism have become effective in explaining the different parts of the integration process. For example, the first version, "historical institutionalism", represented by Mark Pollack and Paul Pierson ${ }^{4}$, is about how institutions affect and change behaviours and decisions of actors. The second version, "rational choice institutionalism" means that "institutions have effects upon the ways in which actors pursue preferences" (Shepsle, 2008:23-38). This analysis can explain why the member states of the EC/EU - as principals - work through the common institutions like the Commission - as an agent in the foreign policy (Delreux and Adriaensen, 2017:326-328). The third version, "sociological institutionalism", pays attention to the culture of the institutions. It can explain the EC/EU identity, shared norms and values between the member states. In fact, "sociological institutionalism" is closely related with the "constructivist" approach of IR theory.

Constructivism (social constructivism) indicates that the interests of states are socially constructed rather than pre-given. This means that the shared assets in communities constitute the main rules of the international system. Therefore, constructivism provides the constitutive elements of the EU foreign policy by focusing on ideas, values, roles, and identities. In other words, the constructivists are interested in how European identities emerge through the use of language, the deployment of ideas, and the establishment of norms. Thus, it seems that "pursuing identity objectives was just as important as a desire to realize external objectives in the development of EU foreign policy" (Delreux and Adriaensen, 2017:326-328). Moreover, Ulrich Sedelmeier has emphasized the EU's enlargement policy process as the core for the EU identity formation. She pointed out how "this process of identity formation might affect European foreign policy" (Sedelmeier, 2003:11-15). In this context, the constructivists argue that the norms and the values in the minds of policy-makers can not only influence the formation of new policies but also affect the limitations on interests (Orbie, 2008:2).

Similarly, Europeanization is a normative and socio-political approach. It explains change and development of domestic actors, institutions, and values of states (Öner, 2014:25). Europeanization also explains a common identity, which reflects the European norms and values that people attach to the EU within the context of the European integration process (Diez et al., 2005:2-7) Although Europeanization has different effects on different states because of their different political cultures and social structures, it shares common values and norms, as well (Öner, 2014:24). For example, the EU member states share some norms on foreign policy such as adopting common positions and implementing joint actions as well as using diplomatic instruments in resolving problems. This means that the EU member states prefer civilian and economic instruments to achieve foreign policy issues. European norms on foreign policy are; adopting joint positions and common actions, cooperating to formulate policies in different areas, and using multilateral, diplomatic instruments in resolving disputes (Müftüler-Baç and Gürsoy, 2010:408). They also consider nongovernmental civil society organizations more influential in defining their foreign policy interests (Oğuzlu, 2010-2011:660, 661). Thus, Europeanization is effective either through formal decisions among the EU member states such as Common Foreign and Security Policy

\footnotetext{
${ }^{3}$ The neo-functionalist approach was based on the seminal work of Haas, E. (1958). The Uniting of Europe: Political, Social, and Economical Forces, 1950-1957. Stanford: Stanford University Press. In his book, Haas wanted to develop a "Grand Theory" explaining the foundations of the European integration process. This work has attracted the attention of other researchers who contributed to this approach with their invaluable studies in the 1960s and the 1970s: Leon N. Lindberg, N. L. (1963). The Political Dynamics of European Economic Integration. Stanford: Stanford University Press; Lindberg, N. L. and Scheingold, A. S. (1970). Europe's would-be Polity: Patterns of Change in the European Community. Englewood-Cliffs, NJ: Prentice Hall.

${ }^{4}$ For more information, see: Pollack, A. M. (2005), The Engines of European Integration, Delegation, Agency, and Agenda Setting in the EU. Oxford and New York: Oxford University Press; Pierson, P. (2004). Politics in Time, History, Institutions and Social Analysis. Princeton and Oxford: Princeton University Press.
} 
(CFSP) or through informal, civilian interactions between the EU member states and third countries (Müftüler-Baç and Gürsoy, 2010:408).

Although Europeanization has intended to transform the member states, later it has become an effective instrument for third countries with an understanding of "Europeanization beyond Europe" (Öner, 2014:23). Therefore, Europeanization has contributed not only to socio-political change but also to the rearrangement of the foreign policies of third countries. Europeanization of foreign policy-making for third countries is related to changes in their decision-making procedures. For example, if there are actors other than democratically elected officials in third countries, the Europeanization process would lessen the role of these actors on foreign policy decision-making. Therefore, democratic institutions' role in decision making is civilian instruments (Müftüler-Baç and Gürsoy, 2010:406).

Europeanization through "conditionality" is specifically related with the interaction between the EU and third countries. In other words, the European Union, as a normative power supports the principle of conditionality in agreements with third countries. For example, the EU has expected the countries in the Western Balkan region to transform the perceptions held by the societies to change their values and norms in order to comply with the identity and the rules of the EU. Thus, the essence of the EU foreign policy is about transforming the identity and shaping the ideas about "the other" (Delreux and Adriaensen, 2017:326-328). In other words, the EU norms and values affect the actions of actors (Daniel, 2011:201, 211). In this context, we can refer to some normative principles influencing the EU foreign policy, such as sustainable peace; social freedom; consensual democracy; associative human rights; supranational rule of law; inclusive equality, social solidarity; sustainable development and good governance (Rosamond, 2014:218).

\subsection{History}

The historical background of the European integration process can inform us about the developing of the EU foreign policy and its instruments, in the course of time. As a matter of fact, the EU foreign policy has developed from an "informal intergovernmental 'gentlemen's agreement' with unwritten rules into a system of formal obligations" (Paul, 2008:6). At the Hague Summit Conference on 2 December 1969, the heads of state or government of the member states of the European Community (EC) requested the foreign ministers of the member states to work on improving in the field of political integration and foreign policy. In less than a year, the foreign ministers of the then six member states of the EC prepared the Luxembourg Report on 27 October 1970, containing the objectives and methods of political cooperation in the field of foreign policy.

At the Paris Summit Conference on 21 October 1972, the member states declared their intentions to transform their relations into a "Union". Thereby, the foreign ministers of the member states drew up the Copenhagen Report on 23 July 1973, which obliged the member states to consult each other on important foreign political issues before deciding and implementing their own approaches. Therefore, on 14 December 1973, the foreign ministers of the member states published the "Document on the European Identity", in which they reaffirmed their attitudes on close cooperation in the field of the political integration. They also emphasized their common responsibilities toward the world affairs. Moreover, they articulated for the first time the existence of "European Political Cooperation" (EPC) for taking responsibilities in the way of constituting political unification. At their Paris Summit meeting on 9/10 December 1974, the heads of state or government of the member states emphasized their intention to extend the EPC to all areas of international affairs affecting the interests of the EC. Similarly, in the London Report of 13 October 1981, the foreign ministers of the member states decided to take effective measures to consolidate the administrative base and the decision-making mechanism of the EPC. When the Single European Act (SEA) entered into force on 1 July 1987, formulating and implementing the European foreign policy has gained formal importance in the side of the member states' governments. Later, the EPC was replaced by CFSP, as the second pillar of the Treaty on European Union (TEU) (Blair, 2010:79). In fact, the CFSP had intended to help the EU member governments in planning their common foreign policy positions (Peterson and Shackleton, 2006:258). 
All in all, although the EPC played an active role in the Middle East crisis of the 1970s, the Soviet intervention in Afghanistan in 1979 and the Yugoslav War (1991-1995) showed its weakness.

In the early years of the post-Cold War period, when the EU experienced conflicts in the Balkans, it became a necessity for the member states to take conflict prevention and crisis management issues more seriously. In this context, "Petersberg Tasks", which was planned as a contribution to the collective defence through humanitarian, rescue, and peacekeeping missions, became a step to take on the road of this necessity, in 1992. Maybe more importantly, at St. Malo, in December 1998, Britain and France agreed to establish a European military cooperation in coordination with NATO. This initiative created the European Security and Defence Policy (ESDP), at the Cologne Summit of 1999. In the same year, the Treaty of Amsterdam increased the responsibility of the EU in peacekeeping and humanitarian issues.

The early years of the new millennium has witnessed new developments in European security and foreign policy. In 2003, the EU adopted a document called "European Security Strategy", for the first time. The document declared terrorism, proliferation of Weapons of Mass Destruction (WMD), regional conflicts, state failure, and organized crime as key security challenges for the EU. Also, the revised version of the document (2008) underlined "the reinforcement of the rule of law and respect for human rights as indispensable elements of peace-building" (Neuvonen, 2014:3). Although these developments are milestones for the development of the EU foreign policy, the Lisbon Treaty is the real cornerstone for constituting the Foreign Policy Instruments, stemmed from the Union's "external action".

\section{EXTERNAL ACTION}

Although the Constitutional Treaty of 29 October 2004 had set the main objectives of "external action" it was only the Lisbon Treaty which made the real contribution to the activities of the EU in the area of "external action" (Balfour et al., 2015:33). As soon as entered into force, in December 2009, the Lisbon Treaty formalized the objectives of the EU's external action. In this context, the EU's external action is composed of the EU's external trade policy, development cooperation, economic and financial cooperation with third countries, humanitarian aid, sanctions and international agreements. The external action also encompasses the Foreign Policy Instruments to pursue foreign policy goals (Keukelerie and Delreux, 2014:12). In fact, the EU does not have a clear foreign policy strategy but it has three policy aims: promoting European values such as democracy and the rule of law; creating a peaceful environment; and forming a political zone with strong external dimensions (Buonanno and Nugent, 2013:281-286). These policy aims have constituted the EU "foreign policy" as a part of the Union's external action.

The Lisbon Treaty also created the post of HR/VP and the EEAS to support the activities of the external action. The first two paragraphs of Article 27 of the TEU explain the mission of the HR/VP as a coordinator of the Union's external actions. The main responsibility of the HR/VP is to conduct political dialogue by supporting the CFSP/CSDP and ensuring consistency (Jones et al., 2012:650). The EEAS, on the other hand, has been created to support the mission of the HR/VP. In this context, the EEAS, as defined by Article 27 (3) of the TEU, has become an administrative link between the member states' foreign policies and the joint external action of the EU (Helwig, 2015:8). In fact, for the first time in history, a supranational entity was created "to conduct a foreign policy with unified external representation as one of its features" (Kaczynski, 2011:10). In this sense, "the creation of the EEAS has prompted European governments to downscale diplomatic representation in third countries" (Rosamond, 2014:218). Operational since 2011, the EEAS is responsible for providing the consistency and coordination of the Union's external action. The EEAS also prepares and implements policy proposals and recommends a "road map" for success (Crowe, 2008:8). The EEAS had faced some crises, in its first years, such as protests in the Arab World, a NATO intervention in Libya, and a political strife in the Horn of Africa (Smith, 2012:2). However, it nevertheless helped to develop crisis management structures of the EU with the creation of a crisis management board, called "Emergency Response Centre". 
Therefore, both the HR/VP and the EEAS have opened a new era in European diplomacy. They contributed to the strategic planning of the member governments upon different regions such as the Balkans, the Sahel region, and the Horn of Africa (Balfour and Ojanen, 2011:8).

\section{SERVICE for FOREIGN POLICY INSTRUMENTS}

Beyond any doubt, the Lisbon Treaty has strengthened the activities of the EU in the area of external action. Article 21, paragraphs (1) and (2) of the TEU is about the actions of the EU on the international stage. Article 21 (1) explains the principles of actions extending to third countries, such as democracy; the rule of law; and respect for human dignity. Article 21 (2) defines common policies and actions of the Union in order to safeguard its values; consolidate and support democracy ${ }^{5}$. Also, the so-called "foreign, security and defence" aspect of the EU's external relations/actions is defined in article 24 of the TEU as follows: "within the framework of the principles and objectives of its external action, the Union shall conduct, define and implement a common foreign and security policy based on the development of mutual political solidarity among member states, the identification of questions of general interest and the achievement of an ever-increasing degree of convergence of member states' actions" (Nugent, 2010:376).

In this context, the Foreign Policy Instruments (FPI) has five main and three regulatory instruments. Examining these instruments, can show us how the EU is influential upon third countries on the international stage. Understanding the effects of the EU upon third countries, therefore, can give us an insight about the level of political integration of the EU member states. This understanding also tells us the level of position of the EU as an international actor among other major powers in the international system.

\subsection{Common Foreign and Security Policy}

The CFSP as the first main FPI is about the CFSP operations and their finances. This instrument acts through its "implementing bodies" namely; EU Special Representatives (EUSRs), Common Security and Defence Policy (CSDP) Missions, and Non-proliferation and Disarmament (NPD) (Avery and Missiroli, 2007:9-27). EUSRs have provided the Union with representation in countries such as Afghanistan, Georgia, Kosovo, and Sudan that are suffering from crisis situations. The CSDP Missions deals with disarmament and counterterrorism as a part of crisis management (Paul, 2008:14). The EUMA Georgia and the EU NAVFOR Somalia are some crisis management operations (Kaski, 2011:6). Moreover, the civilian CSDP Missions, such as the EUCAP SAHEL Niger (2012), and the EUCAP Mali (2015) have intended to fight against organized crime and anti-democratic practices. Also, the EU Monitoring Mission in Georgia aims to contribute stability in this country. Thus, The CFSP Instrument has played a role in fighting with asymmetric conflicts and the proliferation of WMD. It became partially successful in some African countries.

Moreover, the EU has set out its policy on the Middle East in a series of public statements. The EU policy on the Middle East focuses on coexistence and offered a two-state solution with an independent Palestinian state living side-by-side with Israel (European Union External Action Service. Middle East Peace Process, 2018). Similarly, relations with Eastern European countries, based on the "Eastern Partnership", were established in 2009 to strengthen cooperation and deepen economic integration in the region (Keukelerie and Delreux, 2014:260). In this context, the EU has offered conditional association agreements upon progress in democracy and human rights (Youngs, 2010:61).

\footnotetext{
${ }^{5}$ For an extended analysis of the "external affairs" section in the Lisbon Treaty, see: Piris, J. (2010). The Lisbon Treaty, a Legal and Political Analysis. Cambridge: Cambridge University Press, 238-287.
} 


\subsection{Instrument Contributing to Stability and Peace}

The second main FPI is the Instrument Contributing to Stability and Peace (IcSP), which was created, in 2014 to support peace-building activities in third countries. The IcSP is focused on conflict prevention and conflict management (Whitman and Wolff, 2012:218). With a budget of EUR 2, 3 billion for 20142020 period (Service for Foreign Policy Instruments, 2017), IcSP manages currently around 200 projects in over 75 countries in areas such as mediation and stabilization.

This instrument has taken effective steps for both Arab countries, on the institutional level, and African states, on the regional level. The League of Arab States (LAS) can be an example on the institutional level. Since the launch of the EU-LAS Strategic Dialogue on November 2015, the EU has strengthened its operational cooperation with the League of Arab States, in conflicting areas (JohannsonNogues, 2018). African countries, on the other side, can be an example on the regional level. For this region, the EU adopted a document entitled "The EU and Africa: Towards a Strategic Partnership" in December 2005. The document was based on good governance and economic growth. In 2007, joint EU-Africa Strategy had adopted the Africa-EU Partnership; a political framework based on bilateral relations, and was reaffirmed with EU-Africa Summit, held in April 2014. Moreover, the EU's African Peace Facility for 2014-2016 period has provided the funding for African-led peacekeeping operations as well as for operationalizing the African Peace and Security Architecture (APSA), helping to improve African mechanisms to prevent and manage conflicts and crises (Delegation of the EU to the African Union, 2018).

\subsection{The Partnership Instrument for Cooperation with Third Countries}

The third main FPI is the Partnership Instrument for Cooperation with Third Countries, which was established in 2014 (EU Monitor, 2018). It succeeded the Instrument for Cooperation with Industrialized Countries. This instrument deals with economically developed countries, which share similar values with the EU. In fact, the countries in these regions are major political and trading partners of the EU. Considering industrialized countries, the EU has strong relations with Asian, Latin American and Caribbean countries.

Asia, for example, is composed of high-income industrialized partners. Therefore, development cooperation is high on the EU's agenda with Asia. In fact, the EU is stepping up its support to regional integration through the Asia-Europe Meeting (ASEM), the Association of South-East Asian Nations (ASEAN), the ASEAN Regional Forum (ARF) and the South Asian Association for Regional Cooperation (SAARC). Among them, in 2006 and 2008, ASEM sessions focused on democracy and human rights and Burma was the country, which benefitted much from the sessions (Youngs, 2010:72). This Instrument helps the EU to act as an international actor, in the international system.

\subsection{The Partnership Instrument}

The fourth main FPI is the Partnership Instrument (PI), which was created on 11 March 2014 to promote the EU's strategic interests worldwide through its external strategies, policies, and actions. In this context, the EU offers third countries policy supports to respond global challenges (Marlier and Natali, 2010:93).

The PI has a budget of EUR 954.8 million in 2014-2020 period (International Relations and Resource Mobilization, 2017) to finance the Union's external action. This instrument helps the EU to be part of the global system. In 2006, a "Strategy for a Strengthened Partnership" was adopted between the EU and Pacific Islands to upgrade the relationship to include political issues. In 2012, this approach was complemented by the communication towards a renewed EU-Pacific Development Partnership. In June 2015, the Pacific Islands Forum Secretariat and the EU agreed on the Pacific Regional Indicative Program of 2014-2020, which has promoted regional economic integration, respect for human rights, and economic diplomacy (Saner and Yiu, 2003:12). One of the latest meetings was held among foreign ministers on 25-26 October 2016 in the Dominican Republic to reinvigorate the political relationship, 
which conduced to a new partnership with CELAC (Community of Latin American and Caribbean States).

The PI has also played a role in the EU's relations with the Middle East and North African region (MENA), the Black Sea region (Black Sea Synergy) and the Northern European region (Northern Dimension). These regions are important to understand strategic effects of the EU on third countries. For example, the EU's policy with MENA countries seeks to encourage political and economic reforms (O'Sullivan, 2014:10). These relations can be summed up by both the "Mediterranean Policy" of the EU and the "European Neighbourhood Policy" (ENP). The Mediterranean Policy of the EU was established in November 1995, when the EU announced "Barcelona Declaration" with the aim of promoting peace, stability and prosperity in the Euro-Mediterranean region. The EU's Mediterranean Policy has created the Euro-Mediterranean Agreements (MEDA), as a financial instrument. Later, MEDA has been replaced by the European Neighbourhood and Partnership Instrument (ENPI) as a more flexible, "policy-driven instrument designed to target sustainable development and approximation to EU policies and standards" (Musu, 2010:130).

In 2004, the EU presented the ENP with the objective of strengthening stability, security and wellbeing for all neighbouring countries. The ENP, composed of 16 countries, was planned to balance incentives with sanctions. The ENP can be identified as a regional foreign policy with the aim of developing "privileged relations" with neighbouring countries without giving them the prospect of accession. In May 2011, the EU introduced a "new approach" for the ENP to upgrade objectives and principles. The new goal of this approach was to support "deep democracy". Therefore, "more for more"; "markets, mobility and money"; and "greater differentiation" have become the new principles of the ENP (Keukelerie and Delreux, 2014:254).

The PI has played a role for the establishment of two civilian CSDP missions (crisis management missions) in the Occupied Palestinian Territory, namely the EU Police Coordination Office for Palestinian Police Support (EU POL COPPS) and the EU Border Assistance Mission Rafah (EU BAM Rafah), (Helwig, 2015:3). Both of the missions were formed in 2005 to improve the capacity of the civil police force and to implement the road map principles, respectively. Thus, the EU as a civilian power plays a role not only for enhancing its internal responsibilities, but also for emphasizing its perceptions of interdependence (Lavanex, 2004:694).

The Black Sea Synergy and the Northern Dimension are other examples, indicating the PI's effectiveness in two different regions. Regarding the first one, the EU has issued a Joint Staff Working Document on the Black Sea Synergy (European Union External Action Service, Black Sea Synergy, 2018) on, 20.01.2015. It intends to constitute a framework to ensure coherence and provide policy guidance on transport, energy, and cross border competition. Regarding the second one, initiated in 1999, the Northern Dimension (European Union External Action Service Northern Dimension, 2018) has intended to promote cooperation and sustainable development between the EU and Norway, Iceland, and Russia.

Thus, the PI, as one of the largest instruments of the EU, deals with promoting the Union's interests worldwide through realizing economic transactions, protecting environment and fighting with global challenges. In this context, economic partnership agreements and multiannual indicative programs are implementing bodies of the PI. Therefore, the EU has established close relations with third countries in different regions of the world and has intended to contribute them on political reforms, cross-border competition, transport and energy.

\subsection{Instrument for Democracy and Human Rights}

The fifth main FPI is the Instrument for Democracy and Human Rights (EIDHR), which replaced the European Initiative for Democracy and Human Rights, in 2006. The EIDHR aims at promoting human rights and democracy around the world by supporting international justice, electoral observations and the rights of people (Kurki, 2011:349-366). Electoral observations are particularly important for this instrument. Electoral observations consist of planning, preparing and financing "Election Observation 
Missions" (EU EOMs) of national electoral processes in third countries. These Missions have intended to promote democracy and strengthen democratic institutions on the one hand, and human rights issues and rule of law of the third countries, on the other. For example, the EU has helped the Sahel region countries - Burkina Faso, Chad, Mali, Mauritania, and Niger, which suffer from extreme poverty, high population growth rates, and crimes against humanity. For the last two decades, more than $120 \mathrm{EU}$ EOMs have proved successful worldwide.

In March 2011, the EU has adopted an approach for the countries in the Sahel region. This approach, called "Sahel Strategy" (European Union External Action Service, Strategy for Security and Development in the Sahel, 2018), which aims at helping countries in the wider Sahel-Sahara region to overcome key humanitarian challenges. The EU has also announced a new Regional Action Plan in the Sahel region, in March 2014. Operational since 2015, the Action Plan has been focused on preventing challenges that the peoples of the region have faced.

Moreover, "Strategy for a New Partnership" of 2007 has strengthened ties between the EU and Central Asia through political dialogue; and dialogue on human rights. Similarly, the EU has helped the countries of the Western Balkans to provide stable and prosperous democratic societies. The EU member countries agreed, in1999, to launch the "Stabilization and Association Process" for the Western Balkan countries, comprised of a mixture of trade concessions, economic and financial assistance, and contractual relationships (Keukelerie and Delreux, 2014:143).

\subsection{CFSP Sanctions}

The five main FPI of the EU are supported by three regulatory FPI, as well. CFSP sanctions are the first category of the regulatory FPI and they ensure restrictive measures to achieve the CFSP objectives, including peace, democracy, and the rule of law. Sanctions or restrictive measures are used as foreign policy instruments and aim to bring about change in the activities or policies of states, individuals, and non-state actors (Keukelerie and Delreux, 2014:219). Generally, sanctions can be categorized in three different groups: diplomatic, cultural, and economic (Nino-Perez, 2004:108). Diplomatic Sanctions or military sanctions are implemented to respond military conflicts and civil wars in most of the time. The military sanctions have always been short-lived and the EU has removed them as soon as the situations become normal. For example, although the EU imposed arms embargo to Sudan, in 1994 due to civil war, it resumed political dialogue in 1999 and even agreed the Humanitarian Plus Program, which provided a grant of 15 million euros to improve living conditions in the country (Portela, 2010:67-69). Similarly, the EU had imposed arms embargo against Democratic Republic of the Congo (DRC), Ethiopia, East Timor ad Nigeria due to civil wars, border conflicts, regional clashes, and authoritarian governments, respectively, in the 1990s. From time to time, the EU used military sanctions with other types of sanctions. For example, the EU imposed arms embargo and visa ban to Uzbekistan due to using force in response to an uprising and killing civilians in 2005. Similar multiple sanctions had been imposed to Burma in the 1990s when the ruling military government refused transition to democracy. These multiple sanctions became effective and in 2007 the EU released Strategy Paper on Burma to normalize relations; and in 2009 EU-Uzbek Partnership Cooperation Agreement was launched (Portela, 2010: 82, 87). Cultural Sanctions cover flight bans and visa restrictions. Flight ban, for example, has only been imposed on Yugoslavia in 1998. Economic Sanctions, such as freezing funds, restrictions on payments and embargo on specific commodities, are the most effective ones. For example, freezing personal funds has been implemented in various countries such as Zimbabwe and FRY. Also, the UNSC has recommended oil embargo against the apartheid regime in South Africa and the EU followed its advice. Moreover, the EU imposed ban on the supply and sale of oil and oil products to the FRY, as an example of embargo on specific commodities. Another example is about Burma. The member states decided to impose a ban on the import of timber and precious gems on Burma, in 2007. One another example can be prohibiting the importation of conflict diamonds, which are supplied by the rebel groups in Africa, that is the subject of the second regulatory instrument, called the "Kimberly Process" (Portela, 2010:55-58). 


\subsection{Kimberly Process}

The second regulatory FPI is known as the Kimberley Process (KP), which was created as an international initiative to eliminate trade in diamonds sold by illegitimate groups in Africa. On June 1998, therefore, the UN Security Council adopted Resolution 1176, prohibiting the purchase of rough diamonds from UNITA, a rebel group in Angola. According to the Resolution, only rough diamonds with official government certificates could be exported from Angola (Bone, 2004:129).

Therefore, in December 2000, the UN General Assembly decided to create the Kimberley Process Certification Scheme (KPCS), representing both the potential and limitations of international governance schemes to control the trade in "lootable" commodities (Hughes, 2006:115). The KPCS, which came into existence in 2003, put forward the importance of controlling the applications and monitoring developments to realize the KP. Beyond any doubt, controlling the applications and monitoring developments are very important to realize the KP. For this, Ian Smillie suggested that if an effective and credible monitoring system is not adopted, the KP will create a false sense of security, allowing conflict diamonds to continue entering the system, and placing the entire diamond industry at risk (Smillie, 2003:51). Thus, the EU member states have made certain arrangements to implement KP because Belgium and Britain are known as important centres for diamond trading. In this context, the Council Regulation (EC) 2368/2002 (Council Regulation 2368/2002, 2017) has set forth the criteria for trading rough diamonds in order to comply with the requirements of the KP. Thus, the European Commission represents the EU in the KP through the EU KP Committee.

\subsection{Prevention of Certain Trade Goods}

The third regulatory FPI is about the Prevention of Certain Trade Goods that could be used for capital punishment or torture. As a matter of fact, the Charter of Fundamental Rights of the EU is the formal EU document to define all of the values and fundamental rights of the EU citizens. Although the text of the Charter was defined in the 2000 Nice European Council, it became binding when the Lisbon Treaty entered into force on December 2009. In this context, the Union's actions on stopping torture and abolishing capital punishment are based on measures to prevent the trade in certain goods that could be used for capital punishment or torture or other inhuman and degrading treatments.

The Council Regulation (EC) No 1236/2005 defined "Community rules governing trade with third countries in goods that could be used for the purpose of capital punishment or for the purpose of torture and other cruel, degrading or inhuman treatment or punishment, and in related technical assistance" (Council Regulation 1236/2005, 2017). The lists of prohibited goods are set out in the Commission Implementing Regulation (EU) No 775 / 2014 such as thumb and finger cuffs and finger screws, bar fetters and weighted leg restraints (Commission Implementation Regulation 775/2014, 2018). This regulation comprises a specific set of rules for the export controls applied to prevent listed medicinal products from being used for capital punishment in a third country.

\section{COMMENTARY}

We can carry out the evaluation of this article in three parts. The first part explains different types of politics - soft politics and hard politics - of the EU foreign policy instruments and their effects upon third countries. The second part mentions different types of sanctions implemented by the instruments and how they affected third countries. The third part is about an inference about the instruments and therefore deals with different reasons of failures of the instruments.

As to the first part, we can make a distinction between soft politics and hard politics. The main FPI are mostly based on "soft politics" and it seems that they have become relatively more influential upon third countries. For instance, multiannual and/or regional indicative programs, offered mostly by the Partnership Instrument (PI) and the Instrument for Cooperation with Industrialized Countries, have taken effect on increasing trade transactions, economic well-being, and political stability on mostly African and Asian countries. These programs have also been active in respect for human rights, transport 
and energy, and cross-border competition for the countries in those regions. The Instrument Contributing to Stability and Peace (IcSP) has offered peace-building measures, conflict prevention arrangements, and crisis management implementations for conflicting places. These applications have also enhanced relationships with regional institutions. Moreover, the IcSP and the Instrument for Democracy and Human Rights (EIDHR) have served to promote democracy and human rights issues. Particularly, the EIDHR has been known for its election observation missions (EU EOMs). By the same token, the civilian CSDP Missions, arranged by the CFSP, have come into play against asymmetric conflicts, proliferation of WMD and consolidation of democracy in the African and the Middle Eastern countries. For example, these civilian missions have helped to form the Palestinian civil police force and therefore strengthened the Palestinian Authority. Similarly, a rule-of-law mission, called EUJUSTLEX in Iraq became effective in efforts to transition to democracy.

The regulatory FPI, on the other hand, are mostly based on "hard politics" and it seems that they have become relatively less effective upon third countries. It has always been difficult for EU member states to find a common ground on applying CFSP Sanctions to third countries since national interests of the member states are still priority on security and defence issues. As a matter of fact, therefore, the regulatory instruments are not so successful or partially successful, at most. In this sense, the member countries have always been reluctant to agree on a common position and implement a joint action. This is why the EU members have been too slow to decide on common positions and step in events on time as we have seen in the Yugoslavian case, in the early 1990s. In other words, uncertainties have led the leaders of third countries not to cooperate with the EU and act accordingly.

As to the second part, we can categorize sanctions as economic measures and politico-military measures, in general. As a matter of fact, different types of sanctions have produced different effects on third countries. For example, economic measures have become effective in Eastern Europe. For example, financial sanctions and restrictions on trade and investment, and especially a ban on petroleum products against Kosovo have caused positive effects in the conflicting area. Moreover, restrictions on export credits and direct payments to state-owned enterprises have forced the Yugoslavian government to cooperate with the EU (Portela, 2010:97-99). Shortly, economic restrictions reducing state revenues have become effective for Eastern European countries. Politico-military measures, on the other hand mostly cover arms embargo, which became successful in some South-eastern Asian countries. For example, imposing restrictions on weapons industry against Indonesia forced the Indonesian government to accept international peace-keeping forces dealing with military conflicts, in the area. Therefore, as a result of this sanction, the military pulled out of Timor and peace was restored in the region. Of course, without the US contribution, it would hardly be easy for the EU to get a favourable result. Therefore, the US presence must be emphasized. However, the CFSP sanctions on re-establishing democratic rules in non-democratic countries did not yield positive result. Indeed, the leaders of undemocratic countries such as Belarus, Zimbabwe, Burma and Nigeria did not cooperate with the EU to adopt democratic principles, rule of law and protection of human rights.

As to the third part, most of the failures have stemmed from both internal and external reasons. We can explain the "internal reasons" of the failure of the EU FPI in four categories. The first category is about the decision-making dynamics of the EU on foreign policy and the failure to reach common positions and implement joint actions. It is a fact that since foreign policy is made by intergovernmental institutions within the decision-making mechanism of the EU, it is still very difficult to produce common positions and implement joint actions on security and defence matters. There is no doubt that the EU member states have failed to reach common positions and implement joint actions. Of course, if there are no consistent common positions, we cannot mention impressive joint actions in international arena. For example, the EU member states did not agree on a common position for the Durban Review Conference against Racism, although the topic has always been crucial for the European countries. Similarly, the lack of consultation and cooperation had created some problems in the EU's attempts on forming strategies or planning association agreements with third countries. That is why EU's Africa Strategy did not yield any positive result. Moreover, the EU member states had difficulty in deciding appropriate measures or sanctions, with wrong targets, from time to time. For instance, in the SubSaharan Africa where countries were mostly suffer from commercial/trade problems, the EU had 
imposed arms embargo to the countries in the region and of course, it did not resolve trade problems of them.

The second category is about the reluctance of the EU member states on deciding some foreign political issues because of their changed priorities on some regions, and third countries, in the world. Indeed, the EU has lost its interest in some regions, after the Cold War. Although the member states had agreed to contribute to the activities of post-colonialism in Africa and to conclude association agreements with the regional countries supplying privileged positions, in the Cold War years; they have become reluctant to sign preferential agreements with the regional countries after the Cold War period. By the same token, the changing global political and commercial dynamics that is shifting the area of interest to Southeast Asia, and disagreements among member countries about the essence of the instruments - whether implementing different types of sanctions or providing financial aid for certain sectors - can be reasons of declining interest of the EU towards some areas of interest, and mostly towards Africa. Thus, changing global dynamics and differentiated national preferences of the member states have changed the priorities of the EU and reduced the attractiveness of some regions, like Africa.

The third category is about making mistakes on planning, imposing, and implementing sanctions on the third countries. Sometimes, the EU has made mistakes on planning, imposing, and implementing sanctions, which have targeted mostly the African countries. In this sense, both the main and the regulatory instruments did not work, from time to time. For example, humanitarian aid granted to DRC and Sudan failed because the warring parties had seized them. Similarly, the suspension of development cooperation did not work for Nigeria because this country is relatively a rich one in its region and this type of restriction did not affect the Nigerian government. Also, the EU imposed miscalculated measures on the Eastern Balkan countries. For example, in the Balkans, the EU sanctions against FRY had failed because the content of the sanctions were so limited that even humanitarian regulations had been neglected (Portela, 2010:72-77).

The fourth category is to apply inappropriate or inadequate measures to the third countries. In fact, The EU has imposed inadequate measures to third countries, in different parts of the world. For example, in Eastern Europe and in Africa, economic and military restrictions could have been supported by humanitarian measures. Mostly unidirectional restrictions did not yield results since they did not touch upon people or their necessary needs. For instance, the arms embargo accompanied only by a visa ban in the case of DRC did not become effective. It is not difficult to understand that sanctions, in Africa, have become effective when the member countries have decided a combination of measures against the African countries.

Although most of the failures stemmed from internal inconsistencies, sometimes "external reasons" had created barriers in front of the EU attempts. For example, EU arms embargo on Sudan failed because other third countries such as China, Iran and Iraq supported Sudan militarily. Moreover, some international organizations have directly involved in crisis management situations. For instance, the EU has shared most CSDP operations on refugee movements with UN and/or NATO.

Although the EU FPI could not be able to meet the expectations of the member states, it would be unfair to declare it totally useless. It is important to note that the member states have taken lessons from the actions of the FPI. For example, they have understood that cooperation and coordination are equally important for exchanging views on national foreign policies in order to prevent implementing inappropriate and inadequate FPI. In a similar way, the member states have found that implementing mutually comprehensive measures at the same time could be much more effective. It seems that when the EU applied comprehensive sanctions against third countries, they obtained positive results, from them and these sanctions have changed the behaviours of the governments of the third countries, as we have seen in Africa, mostly. Therefore, these lessons can strengthen the external and the Commission Service for the EU FPI on the road of the political integration.

Therefore, the EU FPI has differently affected third countries in different parts of the world. It has not affected any third country at all. In other words, the EU FPI or the interplay between the EU and third countries has become effective in some cases but they have played no role in affecting the behaviours or decisions of the governments of the third countries, in most of the cases. Thus, the member 
states have failed in most cases because they could not be able to create a common denominator reflecting their common positions, dealing with disputed subjects and problematic areas in third countries.

\section{CONCLUSION}

In International politics, states use foreign policy instruments to achieve their political and economic objectives. These instruments are tools that are used not only for consolidating stability internally, but also for indicating power externally. In parallel with states, the European Union, as the most advanced regional, intergovernmental organization, has foreign policy instruments as well. The EU takes advantage of these instruments to bring the member states together on the road of the political integration, internally, and impose them upon the third countries and other international actors to show its global power, externally.

The EU FPI has different characteristics and therefore they have different effects on third countries. For example, CFSP, IcSP, and EIDHR have politico-military characteristics and they aimed to help the third countries in turbulent areas such as Africa and the Middle East. These instruments have intended to fight against terrorism and organized crime and support democracy, peace, and human rights issues in those countries. Partnership Instruments, on the other hand, have mostly socio-political and economic characteristics. These instruments mostly targeted underdeveloped third countries to help them to overcome global challenges, and developed partner countries, which share common interests with the EU member states. Generally, the EU FPI has provided financial aids for these countries to promote joint actions.

For the last decade, the European Union has been trying to develop and consolidate its foreign policy through different instruments. In fact, the EU institutions, and especially the Commission have exerted great effort not only to render EU policies, such as CFSP and CSDP more functional, but also they have tried to make a great impact upon the neighbouring states and third countries with an intention of constituting soft power for these states. However, both the main and regulatory FPI exposed that the EU member states are not yet so effective to constitute a framework leading to a political integration.

\section{REFERENCES}

AVERY, G., MISSIROLI, A. (Eds.) (2007). The EU Foreign Service: How to Build a More Effective Common Policy. EPC Working Paper (No. 28), European Policy Centre, Brussels.

BALFOUR, R., CARTA, C., RAIK, K. (Eds.) (2015). The European External Action Service and National Foreign Ministries, Convergence or Divergence. Ashgate, Surrey.

BALFOUR, R., OJANEN, H. (2011). Does the European External Action Service Represent a Model for the Challenges of Global Diplomacy? Istituto Affari Internazionali Working Papers (No. 11). IAI, Rome.

BLAIR, A. (2010). The European Union since 1945, Pearson, Harlow BISCOP, S. (2013). Europe and the World or Snow White and the Seven Fallacies, Egmont Paper (No.61), Academia Press, Gent.

BONE, A. (2004). "11. Conflict Diamonds: The De Beers Group and the Kimberley Process", (Eds.) ALYSON J. K. Bailes and Isabel FROMMELT. Business and Security: Public-Private Sector Relationships in a New Security Environment, Oxford University Press, Oxford, New York.

BUONANNO, L., NUGENT, N. (2013). Policies and Policy Processes of the European Union, Palgrave-Macmillan, London.

CINI, M., BORRAGAN, N. (2013). European Union Politics. Oxford University Press, Oxford. 
COMMISSION IMPLEMENTATION REGULATION (EU) 775/2014, (2018). Access to European Union Law. https://eur-lex-europa.eu/legal-content/EN/TXT/?uri=celex\%3A32014R0775, (13.04.2018).

COUNCIL REGULATION (EC) 2368/2002. (2017). Implementing the Kimberly Process Certification Scheme for the International Trade in Rough Diamonds, http://europa.eu/LexUriServ, (18.12, 2017).

COUNCIL REGULATION 1236/2005. (2017). Concerning Trade in Certain Goods which could be used for Capital Punishment, Torture or other Cruel, Inhuman or Degrading Treatment or Punishment, https:// eur-lex.europa.eu/eli/reg/2005/1236/oj, (18.12.2017).

CROWE, B. (2008). The European External Action Service, Roadmap for Success. Chatham House, Royal Institute of International Affairs (No.8). Chatham House, London.

DANIEL, T. C. (2011). Making EU Foreign Policy: National Preferences, European Norms and Common Policies, Palgrave Macmillan, New York.

DELEGATION of the EU to the AFRICAN UNION. (2018) African Peace Facility Annual Report 2016 , https://www.africa-eu partnership.org/sites/default/files/document/apf_ar2016_en_v_web.pdf, (12.04.2018).

DELREUX, T., Adriaensen, J. (2017). (Eds.). The Principal-Agent Model and the European Union, Palgrave Macmillan, London.

DIEZ, T., Agnantopoulos, A., Kaliber, A. (2005). "File: Turkey, Europeanization and Civil Society: Introduction", South European Society and Politics, 10(1):1-15.

EU MONITOR. (2018). Regulation (EU) 234/2014 of the European Parliament and of the Council of 11 March 2014 Establishing a Partnership Instrument for Cooperation with Third Countries, https://www.eumonitor.eu/9353000/1/j9vvik7mlc3gyxp/viv7tfy.t3mx6, (12.04.2018).

EUROPEAN UNION EXTERNAL ACTION SERVICE. (2018). Middle East Peace Process, https://eeas.europa.eu/headquarters/headquarters-homepage/337/middle-east-peaceprocess $\neg$ _en, (12.04.2018).

EUROPEAN UNION EXTERNAL ACTION SERVICE. (2018). Black Sea Synergy, https://eeas.europa.eu/heagquarters/headquarters-homepage/346/black-sea-synergy_en, (12.04.2018).

EUROPEAN UNION EXTERNAL ACTION SERVICE. (2018). Northern Dimension, https://eeas.europa.eu/headquarters/headquarters-homepage_en/347Northern\%20Dimesion, (12.04.2018).

EUROPEAN UNION EXTERNAL ACTION SERVICE. (2018). Strategy for Security and Development in the Sahel, https://eeas.europa.eu/archives/docs/africa/docs/sahel_strategy_en.pdf, (12.04.2018).

HELWIG, N. (2015). Fine-Tuning EU Foreign Policy, a Joint Approach between the New Commission and the European External Action Service. The FIIA, Briefing Paper (No.168), FIIA, Helsinki.

HENIG, S. (2002). The Uniting of Europe, Making of the Contemporary World. Routledge, New York.

HUGHES, T. (2006). "Conflict Diamonds and the Kimberley Process: Mission Accomplished or Mission Impossible?" South African Journal of International Affairs, 13(2):115-130. 
INTERNATIONAL RELATIONS and RESOURCE MOBILIZATION. (2017). Partnership Instrument, http://icr.unwto.org/content/partnership-instrument-pi, (09.10.2017).

JOHANNSON-NOGUES, E. (2018). The New EU-Arab League Dialogue: The Counters of a Cooperation, (12.04.2018).

JONES, E, MENON, A., WEATHERILL, S. (2012). The European Union, Oxford University Press, Oxford.

KACZYNSKI, P. M. (2011). Swimming in Murky Waters, Challenges in Developing the EU's External Representation. The FIIA Briefing Paper (No. 88), FIIA, Helsinki.

KASKI, A. (2011). The CSDP after Lisbon: Lost Opportunities or Changed Interests? Geneva Centre for Security Policy, Policy Paper. (No. 16), GCSP, Brussels.

KEUKELERIE, S., DELREUX, T. (2014). The Foreign Policy of the European Union, (2nd Ed.), Palgrave Macmillan, New York.

KURKI, M. (2011). Governmentality and EU Democracy Promotion; the European Instrument for Democracy and Human Rights and the Construction of Democratic Civil Societies, International Political Sociology, http: // onlineliberary.wiley.com/doi/10. 1111/j.1749-5687. 2011. 00139. X/, 349-366, (20.07.2017).

LAVENEX, S. (2004). "EU External Governance in 'Wider Europe"”, Journal of European Public Policy, 11(4):680-700.

MARCH, J. G., OLSEN, J. P. (1984). "The New Institutionalism: Organizational Factors in Political Life", The American Political Science Review, 78(3):734-749.

MARLIER, E., NATALI, D. (Eds.) (2010). Europe 2020. Towards a More Social EU? Peter Lang, Brussels.

MITRANY, D. (1943). A Working Peace System: An Argument for the Functional Development of International Organization, Royal Institute of International Affairs, London.

MUSU, C. (2010). European Union Policy towards the Arab-Israeli Peace Process, the Quicksand of Politics, Palgrave Macmillan, New York.

MÜFTÜLER-BAÇ, M., GÜRSOY, Y. (2010). "Is There an Europeanization of Turkish Foreign Policy, an Addendum to the Literature on EU Candidates?” Turkish Studies, 11(3):405-427.

NEUVONEN, M. (2014). Towards a Two-State Solution, A New Approach is needed to promote the Middle East Peace Process. FIIA Briefing Paper (No.16), FIIA, Helsinki.

NINO-PEREZ, J. (2004). "EU Instruments for Conflict Prevention" (Eds.) Vincent KRONENBERGER, V. and WOUTERS, J., the European Union and Conflict Prevention, Policy and Legal Aspects. (p. 93-117). T.M.C Asser Press, The Hague.

NUGENT, N. (2010). The Government and Politics of the EU. Palgrave Macmillan, London.

OĞUZLU, T. (2010-2011). "Turkey and Europeanization of Foreign Policy", Political Science Quarterly, 125(4):657-683.

ORBIE, J. (2008). "A Civilian Power in the World? Instruments and Objectives in European Union External Policies" (Ed.) ORBIE, J. Europe's Global Role, External Policies of the European Union, (pp.1-34) Ashgate, Surrey. 
O'SULLIVAN, D. (2014). The EU in the MENA Region: Confounded by the Chaos? GCSP Policy Paper (No.2), GCSP, Geneva.

ÖNER, S. (2014). "Internal Factors in the EU's Transformative Power over Turkey: The Role of Turkish Civil Society", Southeast European and Black Sea Studies, 14(1):23-42.

PAUL, J. (2008). EU Foreign Policy After Lisbon, Will the New High Representative and the External Action Service Make a Difference? Research Group on European Affairs, Policy Analysis (No. 2), C.A.P, Munich.

PETERSON, J., SHACKLETON, M. (2006). The Institutions of the European Union, Oxford University Press, Oxford.

PORTELA, C. (2010). European Union Sanctions and Foreign Policy, when and why do they Work? Routledge, London and New York.

ROSAMOND, B. (2014). “The EU's Normative Power and Three Models of Liberal Communicative Discourse", (Eds.) CARTA, C. and MARIN, J., EU Foreign Policy through the Lens of Discourse Analysis, Making Sense of Diversity, (p. 211-226), Ashgate, Dorchester.

SANER, R., YIU, L. (2003). International Economic Diplomacy: Mutations in Post-Modern Times. Netherlands Institute of International Relations, (No. 84), Clingendael, The Hague.

SEDELMEIER, U. (2003). EU Enlargement, Identity and the Analysis of European Foreign Policy: Identity Formation through Policy Practice. Robert Schuman Centre for Advanced Studies, Working Papers. (RSC No. 13), European University Institute, Florence.

SERVICE for FOREIGN POLICY INSTRUMENTS (2017). Instrument Contributing to Stability and Peace, Preventing Conflict around the World, http://ec.europa.eu/dgs/fpi/what-wedo/instrument_contributing_to_stability_and_peace_en.htm, (02.07.2017).

SHEPSLE, K. A. (2008). Rational Choice Institutionalism in Sarah A. Binder, R. A. W. Rhodes, Bert A. Rockman (Eds.). The Oxford Handbook of Political Institutions (p. 23-38), Oxford University Press, Oxford.

SMILLIE, I. (2003). The Kimberley Process, the Case for Proper Monitoring the Diamonds and Human Security Project. Occasional Paper (No. 5).

SMITH, J. (2012). Fit for Purpose? The European External Action Service one Year On. Oxfam Briefing Paper (No.159).

WHITMAN, R. G., Wolff, S. (Eds.) (2012). The European Union as a Global Conflict Manager. Routledge, London and New York.

YOUNGS, R. (2010). The EU's Role in World Politics, a Retreat from Liberal Internationalism. Routledge, London and New York. 